\title{
In vitro evaluation of antiplasmodial activity of plant samples used in traditional medicine in Benin
}

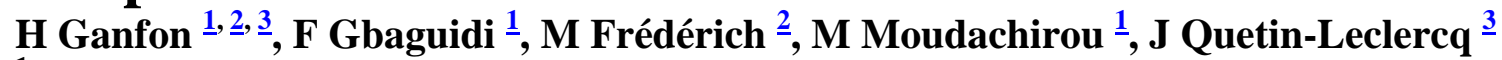

${ }^{1}$ Laboratoire de Pharmacognosie et des huiles essentielles(LAPHE) FAST/Faculté des Sciences de la Santé (FSS) Cotonou -Bénin

${ }^{2}$ Laboratoire de Pharmacognosie, CIRM, Université de Liège (Belgique)

${ }^{3}$ Unité d'analyse chimique et physico-chimique des médicaments et de Pharmacognosie de l'Université Catholique de Louvain (Belgique)

In order to find local alternatives to expensive available antimalarial drugs and solutions to the emergence of drug resistance of $P$. falciparum strains, we undertook the exploration of plants used against malaria in the traditional pharmacopoeia from Benin. We studied samples of 11 plants from the Beninese flora, to evaluate their antiplasmodial activity and their cytotoxicity. Lipophilic extracts of two of the studied plants: Acanthospermum hispidum and Carpolobia lutea showed a very interesting in vitro antiplasmodial activity against the chloroquine $W_{2}$ resistant strain with $\mathrm{IC}_{50}$ of $6.6 \mu \mathrm{g} / \mathrm{ml}$ and $5.7 \mu \mathrm{g} / \mathrm{ml}$ respectively; being less active on the $3 D 7$ sensitive strain ( $\mathrm{IC}_{50}: 12.6 \mu \mathrm{g} / \mathrm{ml}$ and $11.91 \mu \mathrm{g} / \mathrm{ml}$ respectively). Two extracts from other plants showed cytotoxic activity. The methanolic extract of Anchomanes difformis showed toxicity against $W_{38}$ (human embryonic fibroblast; $\mathrm{IC}_{50}: 12.01 \mu \mathrm{g} / \mathrm{ml}$ ) and a lipophilic extract of Vernonia amygdalina against $J 774$ (murine macrophages; IC $_{50}$ : $6.48 \mu \mathrm{g} / \mathrm{ml})$.

Acknowledgements: CUD (Coopération Universitaire au Développement) 